Print ISSN: 2288-4637 / Online ISSN 2288-4645

doi:10.13106/jafeb.2020.vol7.no9.039

\title{
Herding in Fast Moving Consumer Group Sector: Equity Market Asymmetry and Crisis
}

\author{
Bharti BHARTI ${ }^{1}$, Ashish KUMAR ${ }^{2}$
}

Received: July 03, 2020 Revised: July 19, 2020 Accepted: August 10. 2020

\begin{abstract}
This study empirically examines herd behavior for fast moving consumer goods (FMCG) sector stocks under varied market return conditions and the period during the global financial crisis and its aftermath. We examine the sample of stocks trading on the Nifty FMCG Index of the Indian equity market from January 2008 up to December 2018 using the dispersion measure of cross sectional absolute deviation and examine its relationship with the market return to explore herd phenomenon. Quantile regression estimate is used and the results of the study validate rational asset pricing models as the sector does not display herding. In contrast, anti-herd behavior at lower and median quantile values is observed. A possible reason can be the non-cyclical nature of the industry where investors rely more on the fundamentals rather than crowd chasing. We also findthe absence of herd phenomenon during the market asymmetries of bull and bear phases, extreme movements, the period of the global financial crisis, and afterward. We further examine herding under the impact of the information technology (IT) industry and conclude that significant return movements in IT sector impact dispersions in the FMCG industry. Also, there is a co-varying risk between the two sectors confirming the spillover in an integrated market.
\end{abstract}

Keywords: Herd Behavior, Cross-Sectional Absolute Deviation, Quantile Regression, Asset Pricing Models, Global Financial Crisis

JEL Classification Code: G12, G4, C21

\section{Introduction}

Human beings behave normally and not always rationally (Statman, 1999). Their personality affects the investment (Jalal, Zeb,\& Fayyaz, 2019) and financial decisions that are driven by social preferences and biases, lacking self control, and blinded by emotions (Loewenstein, Weber, Hsee, $\&$ Welch, 2001). The investors change their preferences according to past trades and biases (Go \& Lau, 2014). These cognitive biases question the mean variance portfolio theory

${ }^{1}$ First Author. Assistant Professor, University School of Management Studies, Guru Gobind Singh Indraprastha University, Dwarka, Delhi, India [Postal Address: Dwarka, Delhi, 110078, India] Email: bharti.1119@gmail.com

${ }^{2}$ Corresponding Author. Assistant Professor, University School of Management Studies, Guru Gobind Singh Indraprastha University,

Delhi, India [Postal Address: Dwarka, Delhi, 110078, India]

Email: ashish_prl@yahoo.com

(c) Copyright: The Author(s)

This is an Open Access article distributed under the terms of the Creative Commons Attribution Non-Commercial License (https://creativecommons.org/licenses/by-nc/4.0/) which permits unrestricted non-commercial use, distribution, and reproduction in any medium, provided the original work is properly cited. that relies on the assumptions of standard asset pricing and efficient market hypothesis. There exists a disparity between assumptions of financial theories and how investors behave (Daniel \& Titman, 1999; Rubinstein, 2000). The financial market crashes, asset bubbles, and market anomalies have produced ample evidence of how investor psychology impacts investment and financial decision making capability. This has given impetus to the subject of behavioral finance.

According to Sewell (2010), limits to arbitrage and psychology of investors are the pillars of studying behavior finance and its effects on financial markets. The pioneer in the subject was Daniel Kahneman who also propounded the Prospect Theory (1979), according to which investor's assessment of gains and losses is different as they put more emphasis on potential losses rather than an equal amount of gains. Such behavioral reactions affect asset prices (Lakonishok, Shleifer, \& Vishny, 1992). One such behavioral bias that originates as investors behave collectively is herding which is a situation where humans overlook their information and converge towards the crowd opinion through imitation (Bikhchandani \& Sharma, 2000). Banerjee (1992) argues that during herding investors make decisions that are in congruence with the crowd, sometimes not even following 
their purpose or simply mimic other market participants' actions (Chiang \& Zheng, 2010).

Historical financial market crashes from the 1630s' of the tulip mania, the internet bubble crash of 2000 s and, the subprime crisis in the year 2008 proves that humans ignore fundamentals and behave collectively. The extant literature argues that a profit maximizing investor herds because of the natural inclination for conformity with the larger crowd (Bikhchandani \& Sharma, 2000). Second, compensation and incentive schemes of money and fund managers are such that imitation is rewarded (Gümbel, 2005; Hedesström, Gärling, Andersson,\& Biel, 2015). On similar lines, money and fund managers herd to safeguard reputation as it helps in avoiding poor relative performance (Scharfstein \&Stein, 1990). Other reasons include the belief that others have more information about an investment or cost of information availability (Kultti \& Miettinen, 2006) or uncertain environment (Baddeley, 2010; Fernández, García-Merino, Mayoral, Santos,\& Vallelado, 2011; Prechter \&Parker, 2007). Herd behavior that results in an inefficient market is called intentional whereas spurious herding is characterized by similar reactions by all investors because of publically available information (Bikhchandani \& Sharma, 2000).

The present study contributes to the empirical evidence of investor herd behavior in India with a focus on industry specific stocks of fast moving consumer group (FMCG) trading on the Nifty FMCG index of the National Stock Exchange. This study finds motivation from the following: first, although the subject of herding is well researched in financial literature, yet there is a paucity of studies that examine the behavior at sector specific level. Literature shows that investors, money, and fund managers use industryspecific information (Choi \&Sais, 2009) for trading decisions and behave like lemmings and crowd around "hot sectors" while selling off the losers. It, therefore, becomes necessary to examine if herding is present at the sector level as any bias can impact the asset prices. Second, the FMCG sector is the fourth largest in the Indian economy and represents huge potential backed by structural growth drivers of online presence, demographic profile, foreign direct investments, increasing disposable incomes and consumption that make the industry interesting to be examined (IBEF Report, June 2020). Next, majority of the studies performed to test herd bias use ordinary least squares regression (OLS) whereas our study uses quantile regression (QREG) estimator (Koenker \& Bassett, 1978) which provides more robust results than OLS and can be used to examine an entire family of curves.

The paper is divided into seven sections. This section is the introduction followed by section 2 that presents the review of existing studies. Significance of the study and its objectives find a place in sections 3 and 4 respectively. Section 5 discusses the sources of data and explains the empirical methodology used. The empirical results, interpretation, and discussion thereon have been provided in section 6 . The last section 7 concludes the paper with the implications of the study.

\section{Literature Review}

\subsection{Herding in Financial Markets}

The academic debate on herd behavior remains vivid and inconclusive with empirical results producing conflicting findings. Keynes (1930) argues that in an imperfect world with information asymmetry and uncertainty, individuals find motivation in herding and crowd chasing because of the general belief that others might be better informed. The mindset of 'animal spirit' (Shiller, 2003) induces the figment of emotion and irrationality among the economic agents making them follow each other blindly. The behavior can be studied at the participant level and from the risk-return relationship of the aggregate market using the measure of dispersion. This section presents a synoptic view of the literature on herding at the aggregate market return level.

The pioneering research by Christie and Huang (1995) uses the cross sectional standard deviation (CSSD) measure of dispersion to examine herding in the equity markets of the US during stress periods. The study concludes no evidence of herd behavior. The measure of CSSD is further improved by using cross sectional absolute deviation (CSAD) (Chang, Cheng,\& Khorana, 2000) to study the equity markets of Hong Kong and the US (no herd pattern), Japan (partial herding), and Taiwan and South Korea (significant herding). They argue that increased herd activity in emerging markets may be due to the limited disclosures, less transparency and efficiency, and higher cost of information acquisition. Studies on Indian and other emerging markets provide mixed results. Lao and Singh (2011) investigate the equity markets of India and China and find evidence of herd behavior. Other noteworthy studies for India (Garg \&Gulati, 2013) and China (Demirer \&Kutan, 2006) conclude no significant herd activity for varied markets return conditions. The European markets of Greece (Caporale, Economou,\& Philippas, 2008), Turkey (Kapusuzoglu, 2011), Italy (Caparrelli, D'Arcangelis,\& Cassuto, 2004) and Central and East Europe (Pochea, Filip,\& Pece, 2017) also show herd behavior. Herd behavior using the measure of CSAD has been studied in other asset classes, for instance, cryptocurrency and results reveal that herd pattern is aggravated during bullish and high volatility periods (Jalal, Sargiacomo, Sahar,\& Fayyaz, 2020).

\subsection{Studies on Herding at Sector Level}

Investors face homogeneous decisions when they have a preference for the same portfolios and as a result herd around 
particular sectors (Bikhchandani \&Sharma, 2000). Diermeier and Solnik (2001) argue that the information pattern at sector level has a significant impact as investors use the sector indices as a benchmark to track the portfolio performance and explain the returns. In a sector specific study, Kumar and Bharti (2017) find that information technology stocks do not herd in India. The study reasons that a lower proportion of retail investor participation compared to institutional investors limit the scope of herding. Ganesh, Naresh, and Thiyagarajan (2016) find no evidence of significant herd pattern in India for any sector with exceptions of cement and automobile for a brief period. On the contrary, information technology sector stocks in China (Lee, Chen,\& Hsieh, 2013) and Malaysia (Dehghani \& Sapian, 2014) display significant herding.

Zheng, Li, and Chiang (2017) analyze nine Asian markets and conclude that herd behavior is stronger for the financial and technology sectors and weaker for the utility industry. Social services and media sector stocks in China engage in the highest degree of herding (Yao, Ma,\& Hi, 2013). Automobile and mineral industries in Tehran (Khoshsirat \& Salari, 2011), banking sector in India (Bharti \& Kumar, 2019) and Turkey (Cakan \& Balagyozyan, 2014) during market upswings and energy, manufacturing, non- durable consumer goods and utility sector stocks trading on the Pakistan Stock Exchange (Akbar, Kumar, Rajput,\& Bhutto, 2019) show herding.

Agriculture, food manufacturing, footwear production, and fuel processing also display herd pattern in the Chinese equity markets (Shah, Khan, Meyer, Meyer,\& Oláh, 2019). The research on European countries using high frequency sample period data also report herding for sectors such as consumer goods, industrial and utilities, and healthcare (Andrikopoulos, Kallinterakis, Ferreira,\& Verousis, 2017). In contrast, the Australian equity market does not engage in herd mentality at the aggregate or industry level (Henker, Henker,\& Mitsios, 2006). Gebka and Wohar (2013) unveil that a few sectors specific indices of oil and gas, basic materials, and consumer services display herding and the deviations are more pronounced for up rather than down market movements. As is evident the extant literature on sector-specific herd behavior is inconclusive and gives mixed results.

\section{Significance of the Study}

There is a growing concern in financial literature about the effect of cognitive biases on market efficiency and asset prices. The present study is a modest attempt to fill the gap by examining herd mentality in the consumer goods sector stocks of the Indian equity market. As the economy faces huge growth potentials, the markets act as an investment magnet for investors where the financial choices are influenced by the diversity of cultures and geographies. Certain other characteristics of the Indian markets, for instance, the proportion of retail investor participation, evolving nature of the financial market, limited information disclosures with a high cost of acquisition and transaction, higher capital controls and government intervention have the potential to cause biases in investment decisions (Lao \& Singh, 2011). It is therefore worthy to study the emerging equity market of India for such bias. However, the current scarcity of empirical research covering the study of behavioral bias at the sector level makes this research work relevant.

This study proposes to bridge the gap in the most comprehensive manner. First, it helps in measuring the dispersions between market and stock returns for varied return conditions including the global financial crisis. Lao and Singh (2011) propose that asymmetrical market movements may magnify the impact of behavioral biases (Tu \& Liao, 2020) and suitable market timing strategies can be devised by investors. Evidence of herding will therefore provide implications for investors and other market participants. Second, our method of dividing the market state into bear and bull is based on the concept of synchronization adopted from Harding and Pagan (2006). To the knowledge of the authors, the present literature on the topic has not used this method of classification of market phases for the Indian equity market. Third, in an integrated financial market, there is always comovement between the sector returns. We study the impact of dispersion and return of the information technology sector on herd behavior in the consumer goods sector. Four, QREG (Koenker\& Basett, 1978) that provides a family of dispersion curves at different quantile levels are used. QREG is a median regression estimator and more robust to the presence of outliers and fits through the complete return distribution as compared to OLS. The present study covers the quantiles from $5 \%$ to $95 \%$ as it helps in analyzing the dispersion in the distribution tails.

\section{Research Objectives}

The current study examines if consumer goods sector stocks trading on the Nifty FMCG Index in India display herding for the sample period beginning January 01,2008 , to December 31, 2018. The paper uses empirical and econometric analysis to study herding in the proposed sector for the entire period under review, during market return asymmetries of up and down swings, extreme market return conditions, and the period of 2008-2009 during the global financial crisis by employing QREG estimator. We also examine if the information technology sector has an impact on herding in the FMCG industry. 


\section{Data and Methodology}

\subsection{Data}

The data for the period January 01, 2008 to December 31, 2018 comprises daily closing values of the Nifty FMCG index and the adjusted closing price of its fifteen constituent company stocks. To decrease the survival bias as the number of stocks does not remain constant over the entire sample period, only thirteen companies for which the data was available for the entire period have been included in the study. Further, to examine and analyze if the information technology sector impacts herding in the FMCG sector stocks, we use the daily adjusted close price of the Nifty IT Index and its seven components. The entire data is extracted from the database of Prowess, for a total of 2716 days.

Table 1 provides the results of descriptive statistics for dispersion (CSAD)and market return of FMCG sector stocks for the period under study. The average daily return for FMCG Index is $0.056 \%$ and varies within the range$8.513 \%$ to $8.303 \%$ with a standard deviation of $1.22 \%$. The mean of CSAD is $1.36 \%$ with a standard deviation of $0.65 \%$. The augmented Dickey-Fuller test t- statistic shows that the series is stationary at level. The Jarque-Bera test value is significant for market return and CSAD implying nonnormal distribution with a leptokurtic feature. Thus, quantile regression estimator is preferred over OLS.

\subsection{Methodology}

The current study examines herding for all market conditions using the dispersion measure of CSAD (Chang et al.,2000) that takes inspiration from CSSD (Christie \& Huang, 1995). However, CSSD has the limitation that it measures herd behavior only during stress times (Chang et al., 2000). Since, herding can arise even during the normal and varied market conditions, Chang et al., 2000. useequation (2) and CSAD is defined as the proximity of market return to the individual share return. It is given by:

$$
\operatorname{CSAD}_{\mathrm{t}}=1 / \mathrm{N} \sum_{i=1}^{N}\left|\mathrm{R}_{\mathrm{i}, \mathrm{t}}-\mathrm{R}_{\mathrm{m}, \mathrm{t}}\right|
$$

Here, $R_{i}$ and $R_{m}$ are the return of the stock $i$ and market $m$, at the time t. The market contains $\mathrm{N}$ number of stocks. The regression equation by Chang et al. (2000) is given by:

$$
\mathrm{CSAD}_{\mathrm{t}}=\beta_{0}+\beta_{1}\left|\mathrm{R}_{\mathrm{mt}}\right|+\beta_{2}\left(\mathrm{R}_{\mathrm{mt}}^{2}\right)+\epsilon_{\mathrm{t}}
$$

Here $\beta$ is the regression coefficient. Valuation models as per traditional finance theories assume that dispersion and market return are linearly related, while during herding this does not hold (Chang et al., 2000). Thus, a non- linear squared term $\left(\mathrm{R}_{\mathrm{mt}}{ }^{2}\right)$ is added to the regression equation to overcome the limitation of non- linearity during herding, and a negative and significant regression coefficient $\beta_{2}$ implies herd behavior. Further to overcome the limitation of multicollinearity between explanatory variables and autocorrelation, an extra term of average market return $\left(\overline{\mathrm{R}}_{\mathrm{m}}\right)$ and 1-day lag of CSAD are added respectively (Yao et al., 2013; Pochea et al., 2017) Following is the regression equation:

$$
\begin{aligned}
\operatorname{CSAD}_{\mathrm{t}}= & \beta_{0}+\beta_{1} \mathrm{R}_{\mathrm{mt}}+\beta_{2}\left|\mathrm{R}_{\mathrm{mt}}\right|+\beta_{3}\left(\mathrm{R}_{\mathrm{mt}}-\overline{\mathrm{R}}_{\mathrm{m}}\right)^{2} \\
& +\beta_{4} \mathrm{CSAD}_{\mathrm{t}-1}+\epsilon_{\mathrm{t}}
\end{aligned}
$$

All the symbols have their usual meanings as explained. The present study uses the QREG method of estimation. QREG is based on the median and less subject to the effect of outliers compared to OLS. Second, QREG helps in the study of extreme returns as it can be used to analyze the entire family of curves of the return distribution. Following is the quantile regression equation:

$$
\begin{aligned}
\operatorname{CSAD}_{\mathrm{t}}(\tau / \mathrm{xt}) & =\beta_{0, \tau}+\beta_{1, \tau} \mathrm{R}_{\mathrm{mt}}+\beta_{2, \tau}\left|\mathrm{R}_{\mathrm{mt}}\right| \\
& +\beta_{3, \tau}\left(\mathrm{R}_{\mathrm{mt}}-\overline{\mathrm{R}}_{\mathrm{m}}\right)^{2} \\
& +\beta_{4, \tau} \mathrm{CSAD}_{\mathrm{t}-1}+\epsilon_{\mathrm{t}, \tau}
\end{aligned}
$$

Here $\tau$ is the quantile of study. Negative and significant $\beta_{3}$ implies herding. The current study uses (4) for $\tau=0.05,0.10$, $0.25,0.50,0.75,0.90$ and 0.95 . The choice of the quantiles is important as it will help in determining if a herd pattern arises at a particular level of the market return distribution.

Table 1: Descriptive statistics

\begin{tabular}{|l|c|c|}
\hline & CSAD $_{\mathrm{t}}$ & $\mathrm{R}_{\mathrm{mt}}$ \\
\hline Mean & 1.368855 & 0.056941 \\
\hline Median & 1.237427 & 0.089944 \\
\hline Maximum & 9.879849 & 8.303774 \\
\hline Minimum & 0.000000 & -8.513102 \\
\hline Std. Dev. & 0.651920 & 1.227986 \\
\hline Skewness & 3.257684 & -0.257944 \\
\hline Kurtosis & 26.60573 & 7.481304 \\
\hline Jarque-Bera & 67938.78 & 2307.828 \\
& $(0.0000)^{\star * *}$ & $(0.0000)^{\star *}$ \\
\hline ADF & -9.288099 & -51.33580 \\
& $(0.0000)^{\star * *}$ & $(0.0000)^{\star *}$ \\
\hline
\end{tabular}

${ }^{* * *}$ significant at $1 \%$ level 


\subsubsection{Herd Behavior under Market Asymmetry of Bear and Bull Phase}

Market return asymmetries have the potential to impact the behavior of investors as they follow each other and herd (Fu \&Lin, 2010; Indars, Savin,\& Lublóy, 2019; Jalal et al.,2020). The present paper uses the concept by Harding and Pagan (2006) that measures business cycle co-movements using the concept of synchronization to define bear and bull phase. The entire sample period focuses on the local peaks and troughs of the stock prices. According to Candelon, Piplack, and Straetmans (2008), the bull phase becomes bearish when prices decline for a substantial time period since the last peak price. Similarly, the bear run turns bull, when prices increase for a substantial period of time since the last trough. The paper employs the non-parametric approach using the temporal behavior of time series data of stock prices to differentiate between bear and bull phase. This helps in the location of turning points of the series for identification of the peak and trough, corresponding to the local maxima and minima. Following the Candelon et al. (2008) approach, if $\mathrm{CV}_{\mathrm{t}}$ is the closing value of the Nifty FMCG Index on day $t$, then a peak occurs when $\mathrm{CV}_{\mathrm{t}}$ reaches its maximum value within a window of 6 months, i.e. $\mathrm{CV}_{\mathrm{t}}>\mathrm{CV}_{\mathrm{t} \pm 6 \text { months }}$ or conversely a trough occurs when $\mathrm{CV}_{\mathrm{t}}<\mathrm{CV}_{\mathrm{t} \pm \text { momonths }}$ (Lee et al., 2013). This method helps in the determination of the bull (bear) period as the time period between two consecutive troughs (peaks) respectively. Following is the regression equation:

$$
\begin{aligned}
\operatorname{CSAD}_{t}(\tau / x t)= & \beta_{0, \tau}+\beta_{1, \tau} \cdot(1-D) \cdot\left|R_{m t}\right| \\
& +\beta_{2, \tau} \cdot D \cdot\left|R_{m t}\right| \\
& +\beta_{3, \tau} \cdot(1-D) \cdot\left(R_{m t}-\bar{R}_{m}\right)^{2} \\
& +\beta_{4, \tau} \cdot D \cdot\left(R_{m t}-\bar{R}_{m t}\right)^{2} \\
& +\beta_{5, \tau} C S A D_{t-1}+\epsilon_{t, \tau}
\end{aligned}
$$

This paper uses the dummy variable (D) approach and $\mathrm{D}=1$ for the bear market, i.e. for $\mathrm{R}_{\mathrm{m}, \mathrm{t}}<0$, and 0 otherwise. Herding is concluded when $\beta_{3}$ (bull) or $\beta_{4}$ (bear) is negative and statistically significant.

\subsubsection{Herding during Extreme Returns}

Next, the paper examines herding during extreme conditions that are characterized when $\mathrm{R}_{\mathrm{m}}$ lies to the extreme left or right of the return distribution (Chang et al., 2000). In the context of this study, extreme up (down) movement is when the market return lies to the right (left) of the upper (lower) limit of the distribution at a 5\% significance level. Following is the equation:

$$
\begin{aligned}
\operatorname{CSAD}_{t}(\tau / x t)= & \beta_{0, \tau}+\beta_{1, \tau} \cdot D \cdot\left|R_{m t}\right| \\
& +\beta_{2, \tau} \cdot(1-D) \cdot\left|R_{m t}\right| \\
& +\beta_{3, \tau} \cdot D \cdot\left(R_{m t}-\bar{R}_{m}\right)^{2} \\
& +\beta_{4, \tau} \cdot(1-D) \cdot\left(R_{m t}-\bar{R}_{m t}\right)^{2} \\
& +\beta_{5, \tau} C S A D_{t-1}+\epsilon_{t, \tau}
\end{aligned}
$$

$\mathrm{D}=1$ when $\mathrm{R}_{\mathrm{mt}}$ lies to the extreme right or left of the distribution for significance level $5 \%$, otherwise $\mathrm{D}=0$. A significant and negative value of the regression coefficient $\beta_{3}$ implies herd behavior for extreme market returns.

\subsubsection{Herd Behavior during the Global Financial Crisis Period}

We divide the period of study into two sub-sample periods to classify the crisis period (January 01, 2008 December 31, 2009) and afterward (January 01, 2010December 31, 2018) (Garg \& Gulati, 2013). Then QREG is applied to equation (4). The significant and negative value of $\beta_{3}$ implies herding.

\subsubsection{Impact of the Technology Sector on Herd Behavior}

The FMCG sector is fast transforming its process as digitization and technology power the growth of the industry and the companies are actively embracing digital technology. We examine if there is an impact of the IT sector on herd behavior in the consumer goods sector stocks. Following equation is used to study the behavior:

$$
\begin{aligned}
\operatorname{CSAD}_{\mathrm{t}}(\tau / x t)= & \beta_{0, \tau}+\beta_{1, \tau} \mathrm{R}_{\mathrm{mt}}+\beta_{2, \tau}\left|\mathrm{R}_{\mathrm{mt}}\right| \\
& +\beta_{3, \tau}\left(\mathrm{R}_{\mathrm{mt}}-\overline{\mathrm{R}}_{\mathrm{m}}\right)^{2} \\
& +\beta_{4, \tau} \mathrm{R}_{\mathrm{IT}, \mathrm{mt}}^{2}+\beta_{5} \mathrm{CSAD}_{\mathrm{IT}, \mathrm{t}} \\
& +\epsilon_{\hat{\mathrm{t}}}
\end{aligned}
$$

Here the CSAD and $\mathrm{R}_{\mathrm{m}}{ }^{2}$ of the IT sector are denoted with the subscript IT for time t. The inclusion of $\mathrm{CSAD}_{\mathrm{IT}}$ and $\mathrm{R}_{\mathrm{m}}{ }^{2}$ improves the explanatory power of the model (Lee et al., 2013).

\section{Empirical Results and Discussion}

Figure 1 shows the plot between $\operatorname{CSAD}_{t}$ and the corresponding values of $\mathrm{R}_{\mathrm{m}}$ for the FMCG Index for the period under study. The relationship appears to be linear and positive. The linearity also holds good even during extreme market returns when CSAD has a positive slope. 


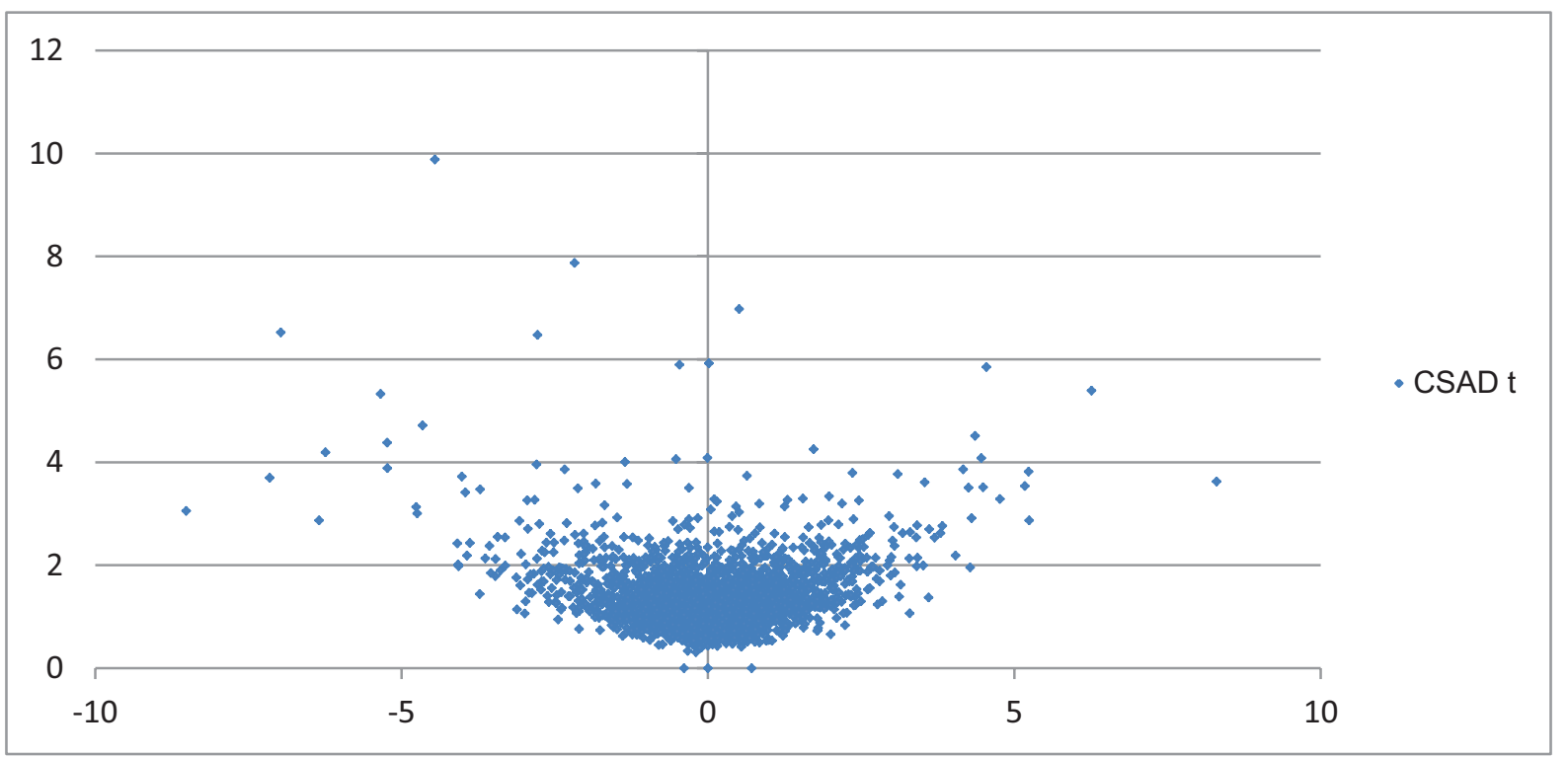

Figure 1: Graphical representation of daily CSAD with market return $R_{m t}$

Table 2: Quantile Regression Results for Aggregate FMCG Sector

\begin{tabular}{|l|c|c|c|c|c|}
\hline$\tau$ & $\boldsymbol{\beta}_{0}$ & $\boldsymbol{\beta}_{1}$ & $\boldsymbol{\beta}_{2}$ & $\boldsymbol{\beta}_{3}$ & $\boldsymbol{\beta}_{4}$ \\
\hline \multirow{2}{*}{0.05} & 0.4437 & 0.0009 & 0.175462 & $0.0104^{* *}$ & 0.0973 \\
& $(18.4907)$ & $(0.0741)$ & $(7.2925)$ & $(2.8395)$ & $(4.9029)$ \\
\hline \multirow{2}{*}{0.10} & 0.4987 & 0.0045 & 0.2154 & 0.0041 & 0.1235 \\
& $(23.0308)$ & $(0.3616)$ & $(9.8053)$ & $(1.3527)$ & $(8.2619)$ \\
\hline \multirow{2}{*}{0.25} & 0.5757 & 0.0189 & 0.1912 & 0.0260 & 0.1996 \\
& $(12.001)$ & $(1.6661)$ & $(2.3797)$ & $(0.7405)$ & $(6.2180)$ \\
\hline \multirow{2}{*}{0.50} & 0.6402 & 0.0308 & 0.1553 & $0.0486^{* *}$ & 0.3308 \\
& $(22.0834)$ & $(2.9156)$ & $(4.1474)$ & $(3.8126)$ & $(15.757)$ \\
\hline \multirow{2}{*}{0.75} & 0.7970 & 0.0087 & 0.1337 & $0.0617^{* *}$ & 0.4328 \\
& $(17.6006)$ & $(0.5803)$ & $(3.7025)$ & $(5.4441)$ & $(13.542)$ \\
\hline \multirow{2}{*}{0.90} & 0.9260 & -0.0100 & 0.1899 & 0.0694 & 0.5374 \\
& $(11.0448)$ & $(-0.4452)$ & $(1.7481)$ & $(1.8105)$ & $(10.642)$ \\
\hline \multirow{2}{*}{0.95} & 1.1111 & 0.0116 & 0.0585 & 0.1191 & 0.6138 \\
& $(7.2532)$ & $(0.1571)$ & $(0.1262)$ & $(0.5596)$ & $(33.491)$ \\
\hline
\end{tabular}

t-statistics in parenthesis ** significant at 5 percent level

Table 2 provides the results for the estimation of equation (4) for FMCG sector stocks trading on the Nifty FMCG Index. The QREG results show that $\beta_{3}$ is not negative for any quantile level. However, it is significantly positive for the quantile values of $5 \%, 50 \%$, and $75 \%$. Thus, FMCG sector stocks trading on Nifty does not herd for the overall sample period. Rather, there is anti-herd activity (Pierdzioch, Rülke,\& Stadtmann,2013) which is demonstrated by positive and significant $\beta_{3}$ Here investors follow their private information and ignore the general market consensus.

Table 3 gives the quantile regression results for asymmetrical market return movements. The table shows significant positive $\beta_{3}$ (anti herding) for quantiles of $25 \%$, $50 \%$, and $95 \%$ for both market phases.

Table 4 gives the estimation results for extreme market conditions using equation (6) in Panel A. The empirical results 
Table 3: Quantile Regression under Asymmetric Market Movements

\begin{tabular}{|c|c|c|c|c|c|c|c|}
\hline \multicolumn{8}{|c|}{ Bull Market } \\
\hline$\tau$ & $5 \%$ & $10 \%$ & $25 \%$ & $50 \%$ & $75 \%$ & $90 \%$ & $95 \%$ \\
\hline $\boldsymbol{\beta}_{0}$ & $\begin{array}{c}0.427 \\
(5.034)\end{array}$ & $\begin{array}{l}0.5437 \\
(4.809)\end{array}$ & $\begin{array}{l}0.7751 \\
(12.58)\end{array}$ & $\begin{array}{l}0.8047 \\
(6.216)\end{array}$ & $\begin{array}{l}0.9091 \\
(5.879)\end{array}$ & $\begin{array}{l}1.0705 \\
(2.038)\end{array}$ & $\begin{array}{c}1.4634 \\
(11.3)\end{array}$ \\
\hline $\boldsymbol{\beta}_{1}$ & $\begin{array}{c}-0.019 \\
(-0.823)\end{array}$ & $\begin{array}{l}0.0012 \\
(0.044)\end{array}$ & $\begin{array}{l}0.0117 \\
(0.547)\end{array}$ & $\begin{array}{l}0.0131 \\
(0.561)\end{array}$ & $\begin{array}{l}-0.0295 \\
(-1.243)\end{array}$ & $\begin{array}{l}-0.0889 \\
(-1.318)\end{array}$ & $\begin{array}{l}-0.0447 \\
(-0.340)\end{array}$ \\
\hline $\boldsymbol{\beta}_{2}$ & $\begin{array}{c}0.15 \\
(0.884)\end{array}$ & $\begin{array}{l}0.0945 \\
(0.379)\end{array}$ & $\begin{array}{l}-0.0188 \\
(-0.277)\end{array}$ & $\begin{array}{l}0.0304 \\
(0.353)\end{array}$ & $\begin{array}{l}0.1287 \\
(1.62)\end{array}$ & $\begin{array}{l}-0.0561 \\
(-0.049)\end{array}$ & $\begin{array}{l}-0.7888 \\
(-2.633)\end{array}$ \\
\hline $\boldsymbol{\beta}_{3}$ & $\begin{array}{l}-0.0004 \\
(-0.006)\end{array}$ & $\begin{array}{l}0.0293 \\
(0.271)\end{array}$ & $\begin{array}{c}0.0744^{* *} \\
(4.109)\end{array}$ & $\begin{array}{c}0.0636^{* *} \\
(2.768)\end{array}$ & $\begin{array}{c}0.0415^{* *} \\
(2.498)\end{array}$ & $\begin{array}{l}0.1388 \\
(0.238)\end{array}$ & $\begin{array}{c}0.5478^{* *} \\
(6.469)\end{array}$ \\
\hline $\boldsymbol{\beta}_{4}$ & $\begin{array}{l}0.1372 \\
(6.77)\end{array}$ & $\begin{array}{l}0.1244 \\
(5.117)\end{array}$ & $\begin{array}{l}0.1147 \\
(4.474)\end{array}$ & $\begin{array}{l}0.2599 \\
(2.561)\end{array}$ & $\begin{array}{l}0.3653 \\
(2.938)\end{array}$ & $\begin{array}{l}0.5224 \\
(2.182)\end{array}$ & $\begin{array}{c}0.5362 \\
(11.4)\end{array}$ \\
\hline \multicolumn{8}{|c|}{ Bear Market } \\
\hline & $5 \%$ & $10 \%$ & $25 \%$ & $50 \%$ & $75 \%$ & $90 \%$ & $95 \%$ \\
\hline $\boldsymbol{\beta}_{0}$ & $\begin{array}{l}0.6534 \\
(6.049)\end{array}$ & $\begin{array}{l}0.7284 \\
(6.351)\end{array}$ & $\begin{array}{l}0.7941 \\
(7.285)\end{array}$ & $\begin{array}{l}0.7694 \\
(9.548)\end{array}$ & $\begin{array}{l}0.7399 \\
(6.850)\end{array}$ & $\begin{array}{l}1.0719 \\
(5.691)\end{array}$ & $\begin{array}{l}1.3388 \\
(3.928)\end{array}$ \\
\hline $\boldsymbol{\beta}$, & $\begin{array}{l}-0.0138 \\
(-0.492)\end{array}$ & $\begin{array}{l}0.0054 \\
(0.151)\end{array}$ & $\begin{array}{l}0.0295 \\
(1.003) \\
\end{array}$ & $\begin{array}{l}0.0426 \\
(2.210) \\
\end{array}$ & $\begin{array}{l}0.0671 \\
(1.963)\end{array}$ & $\begin{array}{l}0.0661 \\
(0.633) \\
\end{array}$ & $\begin{array}{l}0.0949 \\
(0.694) \\
\end{array}$ \\
\hline $\boldsymbol{\beta}_{2}$ & $\begin{array}{c}0.102 \\
(0.905)\end{array}$ & $\begin{array}{c}0.086 \\
(0.515)\end{array}$ & $\begin{array}{l}-0.0167 \\
(-0.293)\end{array}$ & $\begin{array}{l}0.0042 \\
(0.070)\end{array}$ & $\begin{array}{l}0.0184 \\
(0.225)\end{array}$ & $\begin{array}{l}0.0439 \\
(0.133)\end{array}$ & $\begin{array}{l}-0.0414 \\
(-0.137)\end{array}$ \\
\hline $\boldsymbol{\beta}_{3}$ & $\begin{array}{l}0.0494 \\
(1.233)\end{array}$ & $\begin{array}{l}0.0507 \\
(0.783)\end{array}$ & $\begin{array}{c}0.0818^{* *} \\
(5.400)\end{array}$ & $\begin{array}{c}0.0903^{* *} \\
(5.916)\end{array}$ & $\begin{array}{l}0.0905 \\
(3.677)\end{array}$ & $\begin{array}{l}0.0906 \\
(0.933)\end{array}$ & $\begin{array}{c}0.1504^{* *} \\
(1.592)\end{array}$ \\
\hline $\boldsymbol{\beta}_{4}$ & $\begin{array}{l}0.0068 \\
(0.101)\end{array}$ & $\begin{array}{l}0.0344 \\
(0.568)\end{array}$ & $\begin{array}{l}0.1718 \\
(2.083)\end{array}$ & $\begin{array}{l}0.3307 \\
(6.050)\end{array}$ & $\begin{array}{l}0.5272 \\
(7.734)\end{array}$ & $\begin{array}{l}0.5337 \\
(3.558)\end{array}$ & $\begin{array}{l}0.5075 \\
(2.884)\end{array}$ \\
\hline
\end{tabular}

t-statistics in parenthesis $\quad{ }^{* *}$ significant at $5 \%$ level

show that the value of $\beta_{3}$ is not negative for any quantile. Rather it is positive and significant at the quantile values of $5 \%$, $50 \%, 75 \%, 90 \%$, and $95 \%$. Hence, the fast moving consumer goods sector does not display herd behavior during extreme market movements also. Panel B gives the empirical results for equation (4) for the period during crisis and afterward. We find no evidence of herding for both periods. However, as expected, positive and significant $\beta_{3}$ implies that investors avoid herding after the crisis and follow the fundamentals.

The empirical results using the estimation equation (7) for the impact of the IT sector on herd behavior in the FMCG sector are given in Table 5. The regression coefficient $\beta_{3}$ is significant and positive at lower quantiles of $5 \%, 10 \%$, and higher quantiles of $50 \%, 75 \%$, and $90 \%$. This implies no herd behavior. Incidentally, the coefficient $\beta_{4}$ is negative and significant. The variable $\mathrm{R}_{\mathrm{IT}}^{2}$ implies that extreme movements in the information technology sector impact the dispersions in the FMCG industry. Also, the coefficient of $\mathrm{CSAD}_{\mathrm{IT}}$ is positive and significant across the quantiles implying covarying risk as the dispersions in the IT sector impact the movement in the FMCG industry in the same direction.
The results depict that the Indian FMCG sector exhibits no herd behavior for the aggregate market or during asymmetries. A possible reason is the non-cyclical nature of the sector itself that makes the market participants trade, based on stock fundamentals rather than indulging in heuristics and behavioral biases irrespective of the market asymmetries. FMCG industry in India has witnessed the entry of homegrown brands that have been well received by the consumers. This has increased the competition among the players with many new products being offered. Backed by ever-increasing demand, innovative products, and technology revolutionizing the sector, investors are more likely to trust the fundamentals and trade rationally without crowd chasing. Our results conform with the findings of Dehghani and Sapian (2014) study where consumer sector stocks were not found to herd. On the other hand, Akbar et al. (2019) and Andrikopoulos et al. (2017) find significant herding within this industry. The presence of herding impacts the cost of raising new capital in the financial market, thereby impacting the investments and causing asset mispricing. 
Table 4: Quantile Regression Estimate for Financial Crisis Period

\begin{tabular}{|c|c|c|c|c|c|c|c|c|c|c|}
\hline \multicolumn{4}{|l|}{ Panel A } & \multicolumn{7}{|c|}{ Extreme Market conditions } \\
\hline$\tau$ & 0.05 & \multicolumn{2}{|c|}{0.1} & 0.25 & 0.5 & 0.75 & \multicolumn{2}{|c|}{0.9} & \multicolumn{2}{|c|}{0.95} \\
\hline \multirow{2}{*}{$\beta_{0}$} & 0.472 & \multicolumn{2}{|c|}{0.508} & 0.571 & 0.643 & 0.825 & \multirow{2}{*}{\multicolumn{2}{|c|}{$\begin{array}{c}0.978 \\
(13.174)\end{array}$}} & \multirow{2}{*}{\multicolumn{2}{|c|}{$\begin{array}{c}1.214 \\
(16.89)\end{array}$}} \\
\hline & $(16.859)$ & \multicolumn{2}{|c|}{$(19.81)$} & $(14.1)$ & $(20.108)$ & $(16.048)$ & & & & \\
\hline \multirow{2}{*}{$\beta_{1}$} & 0.166 & \multirow{2}{*}{\multicolumn{2}{|c|}{$\begin{array}{c}0.228 \\
(5.431)\end{array}$}} & 0.26 & 0.201 & 0.117 & \multirow{2}{*}{\multicolumn{2}{|c|}{$\begin{array}{c}0.216 \\
(3.556)\end{array}$}} & \multirow{2}{*}{\multicolumn{2}{|c|}{$\begin{array}{c}0.322 \\
(2.992)\end{array}$}} \\
\hline & $(5.182)$ & & & $(5.572)$ & $(3.1183)$ & $(1.595)$ & & & & \\
\hline \multirow[t]{2}{*}{$\beta_{2}$} & 0.124 & \multicolumn{2}{|c|}{0.188} & 0.15 & 0.161 & 0.105 & \multirow{2}{*}{\multicolumn{2}{|c|}{$\begin{array}{c}0.016 \\
(0.143)\end{array}$}} & \multirow{2}{*}{\multicolumn{2}{|c|}{$\begin{array}{c}-0.217 \\
(-1.455)\end{array}$}} \\
\hline & $(2.18)$ & \multicolumn{2}{|c|}{$(3.454)$} & $(3.053)$ & $(3.033)$ & $(1.595)$ & & & & \\
\hline$\beta_{3}$ & $0.011^{*}$ & 0.00 & & 0.008 & $0.036^{* *}$ & $0.665^{* *}$ & 0.0 & $0^{* *}$ & 0.03 & $38^{* *}$ \\
\hline & $(3.248)$ & $(0.44$ & & $(1.387)$ & $(1.994)$ & $(3.54)$ & $(6.2$ & & $(2.4$ & 58) \\
\hline$\beta_{4}$ & 0.041 & 0.01 & & 0.044 & 0.043 & 0.084 & 0.1 & & 0.2 & 58 \\
\hline & $(1.534)$ & $(0.45$ & & $(1.755)$ & $(1.654)$ & $(2.314)$ & $(2.4$ & 84) & (3.2 & 35) \\
\hline$\beta_{5}$ & 0.084 & 0.01 & & 0.213 & 0.328 & 0.414 & 0.5 & & 0.5 & 96 \\
\hline & $(5.094)$ & $(8.23$ & & $(6.968)$ & (15.024) & $(10.88)$ & (11. & 18) & $(26$. & 247) \\
\hline Panel B & & & isis Perio & & & & Post & Crisis $\mathrm{Pe}$ & iod & \\
\hline$\tau$ & $\beta_{0}$ & $\beta$ & $\beta_{2}$ & $\beta_{3}$ & $\beta_{4}$ & $\beta_{0}$ & $\beta_{1}$ & $\beta_{2}$ & $\beta_{3}$ & $\beta_{4}$ \\
\hline 0.05 & 0.61 & -0.027 & 0.138 & 0.006 & 0.154 & 0.483 & 0.01 & 0.086 & 0.054 & 0.076 \\
\hline & $(7.791)$ & $(-0.983)$ & $(2.481)$ & $(0.77)$ & $(2.64)$ & $(12.067)$ & $(0.776)$ & $(0.842)$ & $(1.136)$ & $(1.456)$ \\
\hline 0.1 & 0.621 & -0.023 & 0.158 & 0.001 & 0.217 & 0.556 & 0.015 & 0.08 & $0.062^{* * *}$ & 0.097 \\
\hline & $(5.306)$ & $(-0.776)$ & (3.204) & $(0.149)$ & $(2.902)$ & $(17.058)$ & $(1.343)$ & $(2.237)$ & $(0.674)$ & $(0.543)$ \\
\hline 0.25 & 0.612 & 0.019 & 0.202 & 0.006 & 0.316 & 0.679 & 0.029 & 0.07 & $0.075^{\star *}$ & 0.123 \\
\hline & (6.783) & $(0.847)$ & $(1.686)$ & $(0.175)$ & $(7.098)$ & $(22.951)$ & $(2.603)$ & $(1.23)$ & $(2.884)$ & $(0.059)$ \\
\hline 0.5 & 0.849 & 0.023 & 0.139 & 0.026 & 0.352 & 0.784 & 0.035 & 0.069 & $0.082^{* \star *}$ & 0.211 \\
\hline & $(10.315)$ & $(1.252)$ & $(1.991)$ & $(1.567)$ & $(8.453)$ & $(21.095)$ & $(3.319)$ & (2.109) & $(8.59)$ & $(11.010)$ \\
\hline 0.75 & 1.126 & 0.021 & 0.054 & 0.052 & 0.419 & 0.938 & 0.023 & 0.087 & $0.092^{* * *}$ & 0.291 \\
\hline & (6.959) & $(0.787)$ & $(0.339)$ & $(1.238)$ & $(6.08)$ & $(20.443)$ & $(1.495)$ & $(2.423)$ & $(14.112)$ & $(12.145)$ \\
\hline 0.9 & 1.38 & 0.028 & 0.155 & 0.053 & 0.423 & 1.038 & -0.014 & 0.077 & 0.124 & 0.432 \\
\hline & $(5.791)$ & $(0.906)$ & $(0.688)$ & $(1.033)$ & $(4.762)$ & $(8.028)$ & $(-0.476)$ & $(0.445)$ & $(1.541)$ & $(0.521)$ \\
\hline 0.95 & 1.537 & 0.071 & 0.171 & 0.036 & 0.525 & 1.136 & -0.005 & -0.153 & $0.238^{* *}$ & 0.592 \\
\hline & (3.926) & $(0.721)$ & $(0.733)$ & $(0.523)$ & (3.149) & $(10.147)$ & $(-0.127)$ & $(-0.633)$ & $(2.107)$ & $(1.592)$ \\
\hline
\end{tabular}

t- statistics in parenthesis ** significant at $5 \%$ level ${ }^{* * *}$ significant at $1 \%$ level

Table 5: Quantile Regression Estimate for the Impact of IT Sector

\begin{tabular}{|l|c|c|c|c|c|c|}
\hline$\tau$ & $\boldsymbol{\beta}_{0}$ & $\boldsymbol{\beta}_{1}$ & $\boldsymbol{\beta}_{2}$ & $\boldsymbol{\beta}_{3}$ & $\boldsymbol{\beta}_{4}$ & $\boldsymbol{\beta}_{5}$ \\
\hline 0.05 & 0.473 & -0.005 & 0.155 & $0.013^{* * *}$ & $-0.002^{* *}$ & $0.076^{* * *}$ \\
& $(20.322)$ & $(-0.422)$ & $(5.864)$ & $(3.559)$ & $(-1.962)$ & $(4.545)$ \\
\hline 0.1 & 0.544 & -0.013 & 0.210 & $0.007^{* * *}$ & $-0.003^{* *}$ & $0.074^{* * *}$ \\
& $(22.608)$ & $(-1.129)$ & $(9.671)$ & $(2.431)$ & $(-2.133)$ & $(4.458)$ \\
\hline 0.25 & 0.681 & -0.025 & 0.178 & $0.031^{*}$ & -0.005 & $0.103^{* * *}$ \\
& $(18.196)$ & $(-3.010)$ & $(3.950)$ & $(1.944)$ & $(-1.115)$ & $(3.421)$ \\
\hline 0.5 & 0.908 & -0.026 & 0.155 & $0.052^{* * *}$ & $0.004^{*}$ & $0.073^{* * *}$ \\
& $(32.770)$ & $(-2.517)$ & $(4.198)$ & $(4.667)$ & $(1.823)$ & $(3.739)$ \\
\hline 0.75 & 1.192 & -0.014 & 0.149 & $0.062^{* * *}$ & $0.007^{* * *}$ & $0.084^{* * *}$ \\
& $(31.521)$ & $(-1.092)$ & $(3.180)$ & $(4.486)$ & $(7.926)$ & $(4.336)$ \\
\hline 0.9 & 1.379 & 0.003 & 0.168 & $0.078^{* * *}$ & $0.004^{* * *}$ & $0.159^{* * *}$ \\
& $(27.351)$ & $(0.188)$ & $(3.771)$ & $(8.226)$ & $(3.604)$ & $(5.149)$ \\
\hline 0.95 & 1.617 & -0.015 & 0.160 & 0.085 & 0.023 & $(0.286)$ \\
& $(5.205)$ & $(-0.289)$ & $(0.787)$ & $(1.102)$ & $(0.292)$ \\
\hline
\end{tabular}

t- statistics in parenthesis *** significant at $1 \%$ level ${ }^{* *}$ significant at $5 \%$ level *significant at $10 \%$ level 


\section{Conclusion and Implications}

The present research attempts to examine herding in FMCG sector stocks trading in the Indian equity market. The empirical results reveal that these stocks do not indulge in herd mentality during normal market conditions or asymmetrical market return conditions of bear and bull phase or during extreme market phases and crisis periods. This study extends its contribution to research in several ways. First, it examines the emerging Indian equity market that has distinct characteristics compared to other markets and is likely to be an outperformer among other Asian countries. Second, the FMCG industry is the fourth largest sector in the Indian economy with an upside growth potential and is backed by strong fundamentals and structural growth drivers like demographic dividends, rising rural disposable incomes, increasing discretionary spending, presence of online and e-commerce market and high urbanization rate. Motivated by the above arguments, the study of this sector assumes critical importance as the investment behavior in this industry can have a significant impact on the overall financial market efficiency. Third, FMCG sector stocks are defensive, recession-proof, and non-cyclical.

The present study attempts to understand if the sector returns are resilient to the market asymmetries and do not indulge in herding. Fourth, we also examine the impact of the information technology sector on herding in consumer goods sector stocks. This has implications for portfolio managers as more diversification is required to manage the idiosyncratic risk (Chang et al., 2000; Economou, Kostakis,\& Philippas, 2011). The paper proposes future research areas on the subject of herding using determinants like liquidity, trade volume, and volatility to get a closer insight into the pattern. Future studies can also examine the effect of macroeconomic variables to distinguish between fundamental and nonfundamental herd behavior. The study has implications for portfolio managers and policymakers. Financial analysts and fund managers have an affectation on a specific sector. The characteristic trading or style investing where investment in specific stocks is done based on certain characteristics such as size, sector or price-earnings ratio can lead to herding. Further, the evidence of herd behavior at industry and sector level implies that market timing strategies can be used for generating abnormal returns.

This study is not free from limitations. First, the empirical analysis uses daily data of the index and its constituent stocks. Since, herd behavior might be a shortlived phenomenon, using high frequency intraday data may provide more accurate results. However, due to the cost constraints and unavailability of intraday data for the sample period, our analysis is limited to the daily data set. Second, other market variables, for instance, liquidity, trade volume, and volatility may have an impact on the behavioral pattern of the investors and investment choices. The present study does not use these variables. However, the inclusion of these may validate or open the empirical results for further discussions.

\section{References}

Akbar, U. S., Kumar, S., Rajput, O., \& Bhutto, N. A. (2019). Do investors herd with industries or markets? Evidence from Pakistan stock exchange. Cogent Economics and Finance, 7(1), 1698089. https://doi.org/ 10.1080/23322039.2019.1698089

Andrikopoulos, P., Kallinterakis, V., Ferreira, M. P. L., \& Verousis, T. (2017). Intraday herding on a cross-border exchange. International Review of Financial Analysis, 53, 25-36. https:// doi.org/10.1016/j.irfa.2017.08.010

Baddeley, M. (2010). Herding, social influence and economic decision-making: Socio-psychological and neuroscientific analyses. Philosophical Transactions, The Royal Society B, 365(1538), 281-290.

Banerjee, A. (1992). A simple model of herd behavior. Quarterly Journal of Economics, 107, 797-818.

Bharti, B., \& Kumar, A. (2019). Do banking sector stocks herd? An anecdote from India. Effulgence, 17(2), 37-51. https://dx.doi. org/10.33601/effulgence.rdias/v17/i2/2019/37-51

Bikhchandani, S., \& Sharma, S. (2000). Herd behavior in financial markets: A review. IMF Staff Papers, 47(3), 279-310. Washington, DC: International Monetary Fund.http:/www.imf. org/External/Pubs/FT/staffp/2001/01/pdf/bikhchan.pdf

Cakan, E., \& Balagyozyan, A. (2015). Sectoral herding: evidence from an emerging market. Journal of Applied Economics Letters, 21(2), 75-79.

Candelon, B., Piplack, J., \& Straetmans, S. (2008). On measuring synchronization of bulls and bears: The case of East Asia. Journal of Banking and Finance, 32, 1022-1035. https://doi. org/10.1016/j.jbankfin.2007.08.003

Caparrelli, F., D’Arcangelis, A. M., \& Cassuto, A. (2004). Herding in the Italian stock market: A case of behavioral finance. The Journal of Behavioral Finance, 5(4), 222-230. https://doi. org/10.1207/s15427579jpfm0504_5

Caporale, G. M., Economou, F., \& Philippas, N. (2008). Herd behavior in extreme market conditions: The case of the Athens stock exchange. Economics Bulletin, 7(17), 1-13.

Chang, E. C., Cheng, J. W., \& Khorana, A. (2000). An examination of herd behavior in equity markets: An international perspective. Journal of Banking and Finance, 24(10), 16511679. https://doi.org/10.1016/S0378-4266(99)00096-5

Chiang, T. C., \& Zheng, D. (2010). An empirical analysis of herd behavior in global stock markets. Journal of Banking and Finance, 34(8), 1911-1921. https://doi.org/10.1016/j. jbankfin.2009.12.014

Choi, N., \& Sias, R. W. (2009). Institutional industry herding. Journal of Financial Economics, 94(3), 469-491. https://doi. org/10.1016/j.jfineco.2008.12.009 
Christie, W. G., \& Huang, R. D. (1995). Following the pied piper: Do individual returns herd around the market?. Financial Analysts Journal, 51(4), 31-37. https://doi.org/10.2469/faj.v51. n4.1918

Daniel, K. D., \& Titman, S. (1999). Market efficiency in an irrational world. Financial Analysts Journal, 55(6), 28-40. https://doi.org/10.2469/faj.v55.n6.2312

Dehghani, P., \& Sapian, R. Z. Z. (2014). Sectoral herding behavior in the aftermarket of Malaysian IPOs. Venture Capital, 16(3), 227-246. https://doi.org/10.1080/13691066.2014.921100

Demirer, R., \& Kutan, A. M. (2006). Does herding behavior exist in Chinese stock markets? Journal of International Financial Markets, Institutions and Money, 16(2), 123-142. https://doi. org/10.1016/j.intfin.2005.01.002

Diermeier, J., \& Solnik, B. (2001). Global pricing of equity. Financial Analyst Journal,57, 37-47. https://doi.org/ 10.2469/ faj.v57.n4.2464

Economou, F., Kostakis, A., \& Philippas, N. (2011). Crosscountry effects in herding behavior: Evidence from four South European markets. Journal of International Financial Markets, Institutions and Money, 21, 443-460. https://doi.org/10.1016/j. intfin.2014.05.008

Fernández, B., García-Merino, M., Mayoral, R., Santos, M., \& Vallelado, G. (2011). Herding, information uncertainty and investors' cognitive profile. Qualitative Research in Financial Markets, 3(1), 7-33. https://doi 10.1108/17554171111124595

Fu, T., \& Lin, M. (2010). Herding in China equity market. International Journal of Economics and Finance, 2(2), 148-156. https://doi.org/ 0.5539/ijef.v2n2p148

Ganesh, R., Naresh, G., \& Thiyagarajan, S. (2016). Industry herding behavior in Indian stock market. American Journal of Finance and Accounting, 4(3/4), 284-308. https://doi.org/10.1504/ AJFA.2016.080734

Garg, A., \& Gulati, R. (2013). Do investors herd in Indian market? Decision, 40(3), 181-196. https://doi.org/10.1007/s40622-0130015-z

Gebka, B., \& Wohar, M. (2013). International herding: does it differ across sectors? Journal of International Financial Markets, Institutions and Money, 23(C), 55-84. https://doi.org/10.1016/j. intfin.2012.09.003

Go, Y.-H., \& Lau, W.-Y. (2014). Asymmetric information spillovers between trading volume and price changes in Malaysian futures market. Journal of Asian Finance, Economics and Business, 1(3), 5-16. https://doi.org/10.13106/jafeb.2014.vol1.no3.5

Gümbel, A. (2005). Herding in delegated portfolio management: When is comparative performance information desirable? European Economic Review, 49(3), 599-626. https://doi. org/10.1016/j.euroecorev.2003.08.009

Harding, D., \& Pagan, A.P. (2006). Synchronization of cycles. Journal of Econometrics, 132(1), 59-79. https://doi. org/10.1016/j.jeconom.2005.01.023
Hedesström, M., Gärling, T., Andersson, M., \& Biel, A. (2015). Effects of bonuses on diversification in delegated stock portfolio management. Journal of Behavioral and Experimental Finance, 7, 60-70. https://doi.org/ 10.1016/j.jbef.2015.07.001

Henker, J., Henker, T., \&Mitsios, A. (2006). Do investors herd intraday in Australian equities? International Journal of Managerial Finance, 2(3), 196-219. https://doi. org/10.1108/17439130610676475

IBEF. (2020). Indian FMCG industry in India industry report. Retrieved April 20, 2020 from https://www.ibef.org/industry/ fmcg.aspx

Indars, E. R., Savin, A., \& Lublóy, Á. (2019). Herding behavior in an emerging market: evidence from the Moscow Exchange. Corvinus Economics Working Papers CEWP No. 2019/01. Corvinus University of Budapest, Budapest, Hungary. Retrieved April 20, 2020 from: http://unipub.lib.uni-corvinus.hu/3865/

Jalal, R. N. U. D., Sargiacomo, M., Sahar, N. S., \& Fayyaz, U. E. R. (2020). Herding Behaviour and Cryptocurrency: Market Asymmetries, Inter-Dependency and Intra-Dependency. Journal of Asian Finance, Economics and Business, 7(7), 27-34. https://doi.org/10.13106/jafeb.2020.vol7.no7.027

Jalal, R. N. U. D., Zeb, N., \& Fayyaz, U. E. R. (2019). The effect of personality traits on employee job satisfaction with moderating role of Islamic work ethics. Journal of Asian Finance, Economics and Business, 6(2), 161-171. https://doi. org/doi:10.13106/jafeb.2019.vol6.no2.161

Kahneman, D., \& Tversky, A. (1979). Prospect theory: An analysis of decision under risk. Econometrica, 47(2), 263-291. https:// doi.org/10.2307/1914185

Kapusuzoglu, A. (2011). Herding in the Istanbul stock exchange (ISE): A case of behavioral finance. African Journal of Business Management, 5, 11210-11218. https://doi.org/10.5897/ AJBM11.1984

Keynes, J. M. (1930). A treatise on money. San Diego, CA: Harcourt, Brace and Company

Khoshirat, M., \& Salari, M. (2011). A study on behavioral finance in Tehran stock exchange: Examination of herd formation. European Journal of Economics, Finance and Administrative Sciences, 32(1), 168-183.

Koenker, R., \& Bassett, G. (1978). Regression quantiles. Econometrica, 46(1), 33-50. https://doi:10.2307/1913643

Kultti, K., \& Miettinen, P. (2006). Herding with costly information. International Game Theory Review, 8(1), 21-31. https://doi. org/10.1142/S021919890600076X

Kumar, A., \& Bharti, (2017). Herding in Indian stock markets: An evidence from information technology sector. IOSR Journal of Economics and Finance, 8(1), 01-07.

Lakonishok, J., Shleifer, A., \& Vishny, R. W. (1992). The impact of institutional trading on stock prices. Journal of Financial Economics, 32(1), 23-43. https://doi.org/10.1016/0304405X(92)90023-Q 
Lao P., \& Singh, H.(2011). Herding behavior in the Chinese and Indian stock markets. Journal of Asian Economics, 22(6), 495506. https://doi.org/10.1016/j.asieco.2011.08.001

Lee, C. C, Chen, P., \& Hsieh, K. M. (2013). Industry herding and market states: Evidence from Chinese stock markets. Quantitative Finance, 13(7), 1091-1113. https:// doi: 10.1080/14697688.2012.740571

Loewenstein, G., Weber, E. U., Hsee, C. K., \& Welch, N. (2001). Risk as feelings. Psychological Bulletin. 127(2), 267-286. https://doi.org/10.1037/0033-2909.127.2.267 •

Pierdzioch, C., Rülke, J. C., \& Stadtmann, G. (2013). Forecasting metal prices: do forecasters herd?. Journal of Banking and Finance, 37(1), 150-158. https://doi.org/10.1016/j. jbankfin.2012.08.016

Pochea, M. M., Filip, A. M., \& Pece, A. M. (2017). Herding behavior in CEE stock markets under asymmetric conditions: A quantile regression analysis. Journal of Behavioral Finance, 18(4), 400-416. https://10.1080/15427560.2017.1344677

Prechter, R. R., \& Parker, W. D. (2007). The financial/economic dichotomy in social behavioral dynamics: The socionomic perspective. Journal of Behavioral Finance, 8(2), 8410. https://doi.org/10.1080/15427560701381028

Rubinstein, M. (2001). Rational markets: yes or no? The affirmative case. Financial Analyst Journal, 57(3), 15-29. https://doi. org/10.2469/faj.v57.n3.2447

Scharfstein, D. S., \& Stein, J. C. (1990). Herd behavior and investment. The American Economic Review, 80(3), 465-479. https://doi.org/ 10.1257/aer.90.3.705
Sewell, M. (2010). Behavioral finance. Working Paper. Cambridge, UK: University of Cambridge.

Shah, S. S. H., Khan, M. A., Meyer, N., Meyer, D. F., \& Oláh, J. (2019). Does herding bias drive the firm value? Evidence from the Chinese equity market. Sustainability, 11(20), 5583. https:// doi:10.3390/su11205583

Shiller, R. (2003). From efficient markets theory to behavioral finance. The Journal of Economic Perspectives, 17(1), 83-104. https://doi.org/10.1257/089533003321164967

Statman, M. (1999). Behavioral finance: Past battles and future engagements. Financial Analysts Journal, 55(6), 18-27. https:// doi.org/ 10.2469/faj.v55.n6.2311

Tu, T.-T., \& Liao, C.-W. (2020). Block trading based volatility forecasting: An application of VACD-FIGARCH model. Journal of Asian Finance, Economics and Business, 7(4), 5970. https://doi.org/10.13106/jafeb.2020.vol7.no4.59

Yao, J., Ma, C., \& He, W.P. (2014). Investor herding behavior of Chinese stock market. International Review of Economics and Finance, 29(Jan.), 12-29. https://doi:10.1016/j. iref.2013.03.002

Zheng, D., Li, H., \& Chiang, T. (2017). Herding within industries: Evidence from Asian stock markets. International Review of Economics and Finance, 51(C), 487-509. https://doi: 10.1016/j. iref.2017.07.005 